\title{
341
}

\section{ONION RAISING;}

\section{WHAT KINDS TO RAISE,}

\section{THE WAY TO RAISE THEM.}

\section{JAMES J. H. GREGORY,}

SEED GROWHR, MARBLEHEAD, MASS.

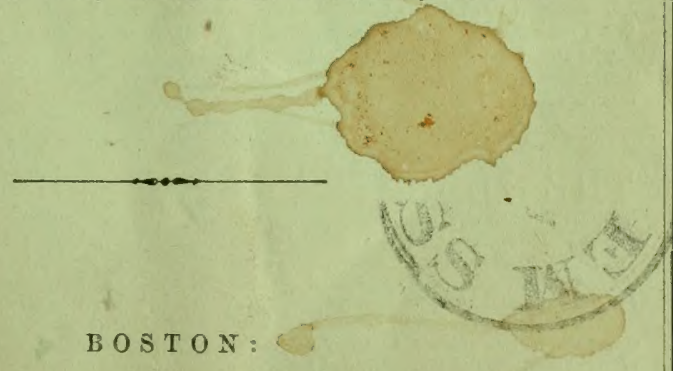

A. WILLTAMS \& COMPANY,

100 Washington Street.

1865 . 


\title{
Che Country (Gentleman:
}

A WEEKLY JOURNAL FOR

\section{THE FARM, THE GARDEN AND THE FIRESIDE.}

\section{LUTHER TUCKER \& sov, Editors and Proprietors, Albany, N.Y.}

The Country Gentleman was selected as an appropriate title for a Journal intended to promote and represent the Improved Agriculture of the whole country, in the widest acceptation of the term. The leading object with its conductors, since its first establishment in 1853 , has therefore been to render it a fitting successor of the old Genese FArMER, established by the senior proprietor Twenty-Two Years before, and of THe CuLtivator as edited by BUEL, and subsequently by himself-with this only difference, that it should ever be found fully up to the Progressive Character and Higher Standard of the Present Day-leading the way to Advancement, wherever advancement is practicable, and presenting always an Accurate anrl Complete Record of the most Successful and Profitable Systems of Farming which Practice evolves or which Science may suggest. In this design the following Departments are included, to all of which there is more or less space devoted in every Volume, and in nearly every Number :

1. Practical Field Husbandry-all the Crops| 6. Progress of Agriculture-Sales and and Processes of Improved Farming.

Shows: New Implements and Inventions.

2. Domestic Animals-Breeds, Diseases, Fat- 7. Rural Architecture-Domestic Econotening and Mariagement.

3. The Darry-Butter and Cheese-the Poul- 8. The Frreside-Travels ; Natural History ; TRY YARD and the A PIART. Home Embellishments and Comfort.

4. Horticultore-Fruits and Fruit Trees: 9. Recond of tHe Times-State of the Crops ; Landscape Gardening; Arboriculture. News at Home and Abroad.

5. Kitchen and Flower Gardening-all Edi- 10. Farm Product Markets-Albany, New ble and Oroamental Plants.

\section{Subscription Price, in Advance, \$2.50 Per Year.}

\section{RECENT NOTICES FRON OUR CONTEMPORARIES.}

The Country Gentlaman.- "Conducted Press of the country. We know of no Journal with a degree of talent that Americans are having so large a number of able practical corproud of. In this respect it is equal to any respondents"-Maine Farmer.

European Journal, and superior to most of "The best of all the American newspapers them."-Gardener's Monthly. devoted to matters of Rural Economy."-Scot-

"Standing at the head of the Agricultural cish Farmer, Edinburgh, Scotland.

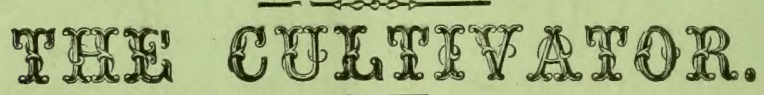

The Cultivator, established in 1834, is still published, and being now made up from the col1 umns of the Coentry Gentleman, it is afforded at the very low price of Eibury Cennts PER Year-all subscriptions begining with the January Number.

The attention of all who do not wish a Weekly [ and most Practical of the Monthly Per Agricultural Journal, should be called to THE cals. Clubbed with the Annual Regrste R CultivatoR, which is at once the Cheapest very favorable terms.

\section{THE ILLUSTRATED ANNUAL REGISTER OF RURAL AFFAIRS.}

\begin{abstract}
This Anndal has now become one of the standard publications of the day, and for the 1 beauty and profusion of its ILlustrations, and the interest and value of its contents, relating to Country Homes, Country LaBors, and Country Luxuries - to all the various branches of Agricultural and Horticultural Practice, it is without an equal in our Rural Literature.

The Publishers of the AxwodL. Rerstrer are/plements and Seeds, or any others who may take prepared to offer the most liberal terms for its an interest in the dissemination of Useful Readintroduction in quantities, either to Agents, $\mathbf{A g}$ - ing and in the Promotion of Rural Improvericultural Societies, Nurserymen, Dealers in im-ment. Single eopies, 30 Cents.

J] All letters should be addressed to
\end{abstract}




\title{
ONION RAISING;
}

\author{
WHAT KINDS TO RAISE,
}

A N D

\section{THE WAY TO RAISE THEM.}

B Y

JAMES J. H. GREGORY,

SFED GROWER, MARBLEHEAD, MASS.

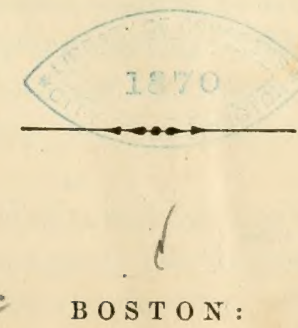

A. WILLTAMS \& COMPANY,

100 Washington Street.

1865 . 
Note. After the first edition had been printed I found that the title of the treatise was so similar to one already published, on the same subject, that the two were likely to be confounded with each other. I have therefore altered somewhat the title; that of the first edition having been " Onions, and how to raise them."

JAMES J. H. GREGORY.]

Marblehead, April, 1865.

Entered according to Act of Congress, in the year 1865, by

JAMES J. H. GREGORY,

in the Clerk's Office of the District Court, of the District of Massachusetta.

Printed at the Salem Observer Office, $226 \frac{1}{2}$ Essex Street, Salem.

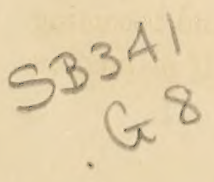




\section{ONION RAISING.}

\section{WHY I WRITE THIS TREATISE.}

In common with my fellow-seedsmen I frequently receive letters from my farmer friends, in different parts of the United States, asking for information on Onion Raising. It is impossible in a letter sheet to give sufficient minuteness of detail; I therefore send out this little treatise, in which I have endeavored to cover very minutely the whole ground of inquiry. I trust that it will prove acceptable.

\section{SELECTING THE SOIL.}

Onions are an exception to the general rule,- they thrive best on old ground, with the exception of an increased liability to injure from rust. I recently examined an acre of land which had been planted continuously with onions for three generations, without perceptible decrease in the quantity or quality of the crop.

Onions are sometimes successfully raised by ploughing up old pasture land in September, thoroughly harrowing it before frost sets in, and in the Spring working in fine manure very thoroughly with the harrow and cultivator. The result of such planting is to get a crop very free from weeds, the great pest of the onion cultivator.

Onions can be raised on a variety of soils, but yield the most satisfactory returns on a sandy loam, a gravelly soil, or, to state a general rule, on those soils which are light in structure. As onions are brought on the heavier soils, the first effect will be a deterioration in their appearance, the outer skin of the yellow varieties losing its fine, clear, translucent yellow, and becoming thieker, duller and less attractive in appearance. If planted on 
a wet, or very heavy soil, the crop will mature late, if it matures at all, giving a large proportion, of that dread of the onion farmer, scallions, or "scullions" as they term them, meaning those whose growth runs mostly to the neck, forming little or no bulb or bottom. With plenty of manure, onions will thrive well on soil that is very gravelly. I have seen very large crops grown on Marblehead Neck, on land so stony, that, after a rain, on an area of many square yards, not a particle of soil could be seen, nothing but small angular fragments of porphyry, with thrifty onions springing as it were out of the very rocks. Let it be understood, however, that this soil was not of a leachy nature, but rested on a hard-pan bottom. The area of land selected should be free of all large stones, as such interfere seriously with the straitness of the rows, the planting, hoeing and general cultivation of so small sized a product. Ultimately good cultivators clear their onion grounds of large loose rocks by blasting or sinking them; obviously the sooner this is done the larger are the returns received from such judicious investments. The land should be laid out in as nearly a square as practicable, as this facilitates estimates of manure, seed, and crops, gives greater regularity to the work, and economizes in the cultivation of a crop which requires a great deal of passing over. To protect the crop from the washing of heavy showers, the land should be level or very nearly so, otherwise a rush of water will bare the roots of some, and heap the earth around the necks of others to the irjury of each.

\section{PREPARING THE SOIL.}

Don't plant a weedy soil to onions, or land which abounds in witch, or Couch grass; if you do you will repent it on your hands and knees all summer long; for such soil will usually require two more weedings than that on which weeds have not been allowed to ripen their seed. To have to keep down witch grass with your fingers in an onion bed is a miserable business, tearing up the onions and your patience at the same time; better delay a year and meanwhile clear the land thoroughly by a diligent use of the cultivator and hoe, finishing in the Fall, 
by throwing the land into ridges that the freezings and thawings of Winter may act destructively on the roots of the witch grass. Should any scattered shoot of this grass show itself in the Spring, let the roots be carefully removed with a fork or spade before the land is ploughed.

In the Eastern States it is found, as a general rule, that success with the first crop of onions is affected by the crop which grew in the land the previous year, and that onions will follow carrots better than any other crop; next to carrots, corn and potatoes are ranked as good preparers of the ground, while to succeed well with onions where cabbage has been raised the previous year is comparatively rare. Were there no other reason, the clean tilth which carrotg insure, makes it an excellent crop to precede onions. In the fertile lands of the West, the method of procedure is briefly this: Land on which grows the bush Hazel is selected, if accessible, the bushes cut down and the turf surface but little more than pared in Spring with the plough. In this condition it is usually allowed to temain as season, exposed to the drying effects of the sun, when it is most thoroughly harrowed and raked, and all the numerous roots and waste is burnt, the land ploughed to a moderate depth, and the seed is sown either broadcast or in drills. Should the early part of the season prove very wet, the crop sowed broadcast is at times smothered under a rapid growth of weeds, while with a favoring season as high as 800 bushels to the acre are harvested.

After the harvesting of the crop which is to precede onions, let the land have a Fall ploughing, and be thrown up into ridges which will not only help destroy noxious weeds and witch grass as above stated, but will leave the land light, in a condition to be worked suecessfully carly in the Spring, a great desideratum for a crop that at times requires the entire season to fully mature it.

\section{THE MANURE.}

Onions require the very best of manure, in the most tempting condition, and plenty of it at that. Guano, Pig manure, Barn Manure, Night Soil, Kelp, Muscle Mud, Superphosphate of Lime, Wood Ashes and Muck are, either alone or in compost, 
all excellent food for the onion. Old ground, to maintain it in first rate condition should receive from six to eight cords of manure to the acre, while new onion ground to get it in first rate condition should receive from eight to ten cords of manure. When Peruvian Guano was held at about sixty dollars per ton, no purchased manure was found to pay as well as this, provided two applications were made, one application of about $500 \mathrm{lbs}$. to the acre, to be raked in at the time of planting, and the other of a like amount to be applied broad cast, when the onions were about half grown. Those who used but one application at the time of sowing were apt to see surprising effects in a fine growth up to the period of half maturity of the crop, and an equally surprising effect in but little growth from this time through to the remainder of the season. Those who have used Guano freely on their onion lands in the vicinity of Philadelphia, assert that one singular result is, that after applying it for three years in succession, the seed onions for the most part fail to sprout, in such soil, and, when seed is planted it makes but little growth after vegetating. As far as I have observed Superphosphate of Lime used as a manure for a series of years is apt to give the first of these results. Pig manure is held in high esteem by many successful growers of onions in southern New England.

In the vicinity of large towns where night-soil can be readily obtained, no more efficient manure can bs applied than a compound of this with muck that has been exposed to a winter's frost, or good loam, in the proportion of three parts muck or loam, to one part night-soil. If with this compost barn manure and sea-manure is mixed, so much the better; for it is a rule for this as for other crops, that a combination of manures in an arithmetical ratio, will produce results nearly approaching a geometrical ratio. To make a compost of loam or muck and night-soil, select a spot very near the piece to be planted, and cover the ground with either to the depth of a foot or eighteen inches; then raise a bank of the same material surrounding this floor to the height of three or four feet, with a thickness of from four to six feet. The carts containing night-soil are 
backed up against this receptacle, and the door being unscrewed the contents shoot out. If barn manure is used it usually forms part of the sides of the receptacle. During the winter the frosts act on the heap to the further sweeting and disintegrating of it, and towards Spring the mass is pitched most thoroughly over, being mixed and made as fine as possible - sand when obtainable having been either previously or being subsequently liberally mixed with it, which so "cuts," or separates it that it remains light and fine. After an interval of about a fortnight, allowing time for fermentation, the heap is again pitched over for fining and mixing, and occasionally, three mixing are made. It would be well for tourists to elide the onion districts at this season of the year, as a little experience will amply satisfy them.

These composts should be made on the ground where the onions are to be planted, for neither onions or any other crop will grow on such spots the same season.

When Superphosphate of Lime is used it is best to make two applications, as with Guano. The results of the use of Superphosphates are not always satisfactory, but I have seen eight hundred pounds applied to the acre produce as good results as that trom seven cords of rich compost applied side by side.

Muscle mud obtained from the sea coast is rarely used alone, though large crops are sometimes raised on old onion ground by the application of this alone, at the rate of eight cords to the acre. $1 \mathrm{t}$ appears to give the best results a few miles inland. The strength and consequent value of this manure varies considerably; and here let me add, that the value of all animal manures will be found to vary greatly; other things being equal, the higher feeding the animal receives, the better the manure.

Wood ashes ig general used in connection with other manures at the rate of about 200 bushels to the acre. Wood ashes should never be combined with other manures, as it will let the Ammonia free, and thus deteriorates their quality. Use ashes either by scattering it on the surface at the time of planting, or when the crop is about half grown.

In the vicinity of large towns, of all manures obtained out- 
side the barnyard, nightsoil is the cheapest. The first farmer who used it in this locality, comparatively but a few years ago, was universally jeered at by his comrades, but now nearly all of our annual crop of 50,000 bushels is fed principally on this manure.

The effect of Kelp, (by this I mean the sea manure which is thrown up by the storms on very bold shores,) when used as the principal manure, is to give a coarse onion, and a very late crop; so late as oftentimes to be in quite a green state at the close of the season, requiring extra labor and care to get it in market condition. In seasons of great drought, however, Kelp serves an excellent end, in so retarding the crop that it is not prematurely ripened. In the excessively dry season of 1864 , crops along the sea coast manured with Kelp in many instances yielded double those manured by barnyard and other manures.

The manure is managed most conveniently by dropping it on the land in quite small heaps, at regular intervals, at convenient distance for spreading. I close this paragraph on manures, hy emphasizing the utility of a thorough fining of it.

\section{PLOWING.}

The farmer who brings up the sub-soil on his onion bed, will find he has made a mistake. Onions do not require deep plowing; four or five inches is sufficient depth to insure a good crop. One of the finest pieces I saw last season was managed by carting on the manure in the Fall, and simply giving it a thorough working into the soil with an ordinary one-horse cultivator, in the Spring, after which the land was raked and planted, no plow, or any implement other than the cultivator having been used. In this instance the soil was naturally quite light. In the West, the ground having been plowed in the Fall, it frequentIy receives only a cultivating or harrowing in the Spring.

As the great object is to get the land in a thoroughly fine condition, to facilitate the covering of the seed with fine earth, to leave the soil light, that there may be a vigorous growth of the plants, and to leave the land in good working 
condition for after culture, no labor should be spared to attain this end. On most soils the ground should be plowed, cross-plowed, and thoroughly cultivated. If from the backwardness of the Spring, and the consequent wet state of the land, the soil should still be at all lumpy, it should be thoroughly rolled before raking for planting, and it is well to brush-harrow it. As onions grown from the seed often. times require the whole season to ripen, the onion grrower breaks ground first of all in his onion bed, springing to this as early in the season as possible to work the land into a light and fine condition.

\section{THE SEED.}

In some localities three pounds and a half of seed was thought sufficient to an acre; afterward this was increased to four, then to four and a half, and now five and six pounds are sometimes planted. Land that is planted to onions the first time requires more seed than old land. If it is designed to pull the onions when small for bunching for the early market, then seven or eight lbs. of seed will be required for an acre. If the intent is to raise the very small onions known as "setts," which are stored over winter to be planted in the spring to produce carly onions, then a much larger quantity will be required. Of crurse it is of the first importance that the seed should be reliable.

Compared with the average return of this crop, the cost of good seed for planting an acre of land to onions, even at the present high prices, is not to be considered a moment beside the acceptance of doubtful seed cven as a gifl; yet every oniongrowing community has its stories to tell of cultivators who have thrown away their time, labor, and manure, by purchasing doubtful seed at a little lower figure than that at which reliable seed could be procured. Others have toiled through the labor of the season, but to find themselves rewarded by a crop of which scullions made a large proportion. I will detail more of this matter of securing good seed, when I come to treat of "Seed Growing." 
The usual test for good seed, that is, seed that will vegetate is, the sinking of it; that which will sink being considered reliable and that which floats being considered worthless. This will answer as a general rule, but it is not wholly reliable. Seed that will sink will not always vegetate, while seed that will float, under some cicumstances, will vegetate. Any farmer who tests his seed by the sinking procesz, will find that much of that which floats will vegetate, while no farmer is safe in planting seed that is two years old, though it will sink. Some farmers ascertained this latter fact to their great loss during the Spring of 1864. If the season is an average one, such seed as is two years old can be relied upon if it has weight sufficient to sink it, but such a season as the Spring of 1864, being unusually wet, much of the tro years seed that was sown, though sown by farmers who had themselves raised it, failed to vegetate.

The lesson to be learned by such unfortunate result, is, that it is never perfectly safe to sow seed that is two years old, and that the only way a prudent cultivator will use it will be when mixed with a large proportion of fresh seed. There are two special risks incidental to the sinking test; the first is the danger that it shall not be thoroughly dried, as onion seed when containing sufficent moisture to cause it to sprout when stored in bulk, appears dry to the eye; again, the vitality of onion seed is very apt to be hurt by the drying of it, particularly so as it is usually deferred until just previous to plantingr when matters are greatly hurried, as the risk of injury through this process is considered too great to permit it to be sunk earlier in the season, when it is likely to be exposed too near the kitching stove. Seed thoroughly winnowed by the wind, on a large sheet spread on some open spot, free from all eddies, will be found to give a quality very nearly or quite as free from light seed as the sinking process. As the objection just presented does not lie against this process, it is decidedly preferable. The only reliable test for the vitality of any variety of seed is that which includes all the usual conditions of growth. Testing by planting in a hot house, or in a box in a common house, are not 
fully reliable, because the seed are not surrounded by the conditions of natural growth-they then have a temperature very mild, and very nearly constant, - with no excess of moisture or dryness, whereas the natural condition of vegetation include the very varying temperature of early Spring, usually a great excess of moisture and a low degree of heat, all of which causes, either single or combined in their effects, draw largely on the vital power of the seed. Hence sced that under the fuvoring influences of the Hot-house or kitchen may vegetate may not have sufficient vitality to overcome the excessive cold or moisture of the garden. The result therefore of the usual experimental tests can be relied upon as giving only approximation to the truth.

Among these approximate tests, is, the simple one of partially filling a tumbler with cotton wool, pouring in a little water, not sufficient to cover the cotton then sprinkle a certain number of seed on the cotton, covering it with a little additional cotton to keep the moisture in. Another simple test is to sprinkle the seed to be tested on a moist woolen cloth, fold the cloth together, and put it in a place moderately warm. The proportion of seed that is good will be known by the proportion that sprout. Experienced eyes can learn something by the appearance and feel of the seed. Old seed require several days longer to vegetate than new seed.

\section{WHAT KIND OF ONIONS TO PLANT.}

Foreign catalogues describe a score and moro varieties of onion which are raised in Europe, but as far as experiments have been made with them in this country, it has thus fur been found that European grown onion seed cannot be relied upon to give as good bulbs as American grown seed of the same varieties; while many sorts are not adapted to our climate. A measure of the doubious quality of this foreign seed is well indicated by the lower price at which it is generally Catalogued.

Of those grown from seed, the Large Red, Yellow, and White, are the three standard varieties in the United States.

The Large Red is commonly known as the Weathersfield Onion, it having been extensively cultivated in that locality at 
an early dily in Onion culture. This is commonly divided into four varieties, viz:

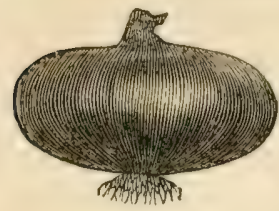

Late LaRge RED, (see illustration) is a very large, thick, late Onion attaining a diameter of from three to six inches, and on the fertile prairies of the West, not unfrequently eight inches.

21. EArLY, which differs only in size and time of ripening; it being rather flatter than the large sort, not so large, and comes to maturity earlier.

Tile Finst Early, is still flatter in form, smaller in size, Jather light colored, and matures earliest of the three sorts; as early as the last of July.

There is also a fine Globe variety of EARLy Red Onion,

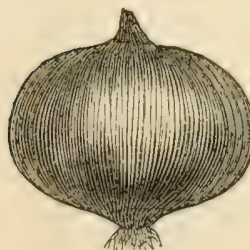
(see illustration) in cultivation, which comes to maturity from a week to a fortnight earlier than the Danvers Early, is of good size and flavor, and in color usually of a very bright, handsome red. The seed of this varicty is much sought after by Onion growers, but is difficult to procure in a pure state.

The very Early Red varieties are not considered as good keepers as the later sorts, but with proper care I find but little diffurence in their keeping properties.

There are four varieties of the Yellow Onion in cultivation, of which the Yellow Flat, called also Yellow Dutch, and Strasburgh, and in the Eastern States the "Silver Skin," is the parent. These varieties are the Common Flat Onion, the Early Cracker Onion, the Danvers Onion, and the Intermediate Onion.

The Crmmon Fuat, (incorrectly called Silver Skin in the Eastern States, a name which properly belongs to the White Portugal, ) is not so generally cultivated since the Early Danvers was introluced, as formerly. It grows to a diameter of about three inches, is compact in its structure and of good flavor. It is a good keeper. 


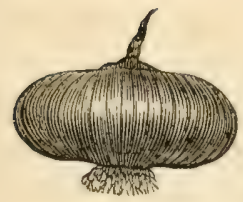
unsurpassed.

The great practical objection io the cultivation of this Onion on an extensive scale, is the extreme care required in handling it ; -it needs as much care to prevent bruising and consequent rotting as an apple. For using in the Fall, this objection would not lie against it with any great force; and when cultıvated for family use greater care might be bestowed upon it than the field crop usually receives. It grows to an average diameter of two and a ha'f inches.

'Tie Early Round Danvers Yellow Onion, was originated by Mr. Daniel Buxton and brother of South Danvers, by careful selections of the roundest and earliest specimens from the Yellow Flat Onion. The Danvers is an early onion, maturing within about a week or ten days of the Early Red and Cracker Onions. It is very prolific, and like the Red Globe Onion, gives larger crops by about one-third than the flat varjeties. When each are seen just before pulling, the difference in the bulk of the crop is not very apparent, but when measured, the globular form of the Danvers "tells." When overgrown by too thin planting of seed this onion is at times rather coarse in structure, but ordinarily it is very compact, fine of structure, heavy, and a good keeper. When well ripened I find it keeps equally well under the same circumstances, as the Common Flat Onion. The earliness of the Danvers Onion is a great gain in short seasons, or very wet ones; and as this onion begins to form its bulb quite early in its growth, " bottom's down," is the farmer's phrase,) it presents marked advantages over the flat sorts for early marketing. At the present time in Boston market the Danvers sells for somewhat more a barrel than the Red. 


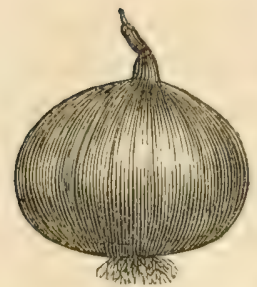

Among experienced growers, and among such only are nice distinctions made, the "DAVE Warren" variety of the Early Round Danvers, (see illustration) is considered to be a very desirable sort. This is generally quite flat on the bottom, with the average shape as given in the engraving. IIaving had considerable experience in selecting onions for seed purposes, I find that I can obtain a greater proportion of handsome, well developed seed onions from this variety than from any other. A person who has not had experience in this would be surprised to find what a difference there is between lots of onions, each of which would be called good onions; from a quantity of the one not a peck of finely developed seed onions could be picked, while from an equal quantity of the other lot a barrel might be selected.

\section{INTERMEDIATE ONION.}

The intermediate onion is a variety half way between the common flat and the Danvers Onions-it being flatter than the Danvers, and thicker than the common flat. It probably originated from the efforts of growers some years since, to produce an onion that should be more oblong, more ergg shiaped than the Danvers; that they might add still more bulk to their crops. The result of such a wide departure from the normal form, during a very wet season was to make quite a proportion of the crop scallions; upon this they went some what to the other extreme and produced the Intermediate Onion, though no variety is more free from scallions than the true Danvers, as I have seen acres of them, on which not a peck of scallions could be found, the entire yield being well matured, of fine size and finely shaped.

The Intermediate Onion is about as early as the Danvers, grows very symmetrical, is very compact and handsome, crops well and keeps well. A casual observer would notice but very little difference between this and the true Danvers.

WHICE PORTUGAL.

The cultivation of this early onion is mostly confined to the 
raising and planting of what are known as 'setts' or button onions, or onions for early family use, as it is a very poor keeper. It is a sweet, mild onion, of a good size for family use, though averaging considerably smaller than the varieties that have been describel. Ilere let me say, that for family use, except for frying, the common onions of the market are much too large to be economical - the two outer layers of an onion three inches in diameter and upwards, though making up about half the bulk of the onion, are usually coarse and tough, and slough off when boiled. The sweetest, tenderest and most economical onion for this purpose of the yellow sort, are those that are from one to two inches in diameter.

'There is usually the distinctions I have here stated between the late and early varieties, but sometimes drought and other causer will almost destroy these distinctions, ripening the very earl and medium early sorts at the same time.

\section{WHAT ONION SHALL I RAISE?}

IIaving described the standard varieties a beginner may query in his mind as to what variety would be most profitable and most reliable for him to cultivate.

The Danvers Onion is the handsomest shaped, yields as much as any other sort, and more than any of the flat varieties per acre. 'Three years since, in the town of Marblehead, over 900 bushels were raised on one acre of land. It is an onion very popular in the eastern market, and in eastern Massachusetts is raised to almost the exclusion of any other variety. The Large Red Onion is quite a favorite in the West, and is considered by some dealers to be the best variety for shipping purposes, though the Danvers is also shipped largely. Those who live in the latitude where the onion is difficult to mature from the seed in one year, affirm that the red onion will mature farther South than any other variety.

After all, whatever suggestions may be offered, the local demand will do most for settling this point. Aside from this, I would recommend the Danvers as, on the whole, the most desirable sort 


\section{ONION SETTS. OR BU'LTON ONION.}

In that portion of the United States south of the vicinity of New York eity, onions cannot be relied on to manure the first year from the seed, owing to the extreme heat of the climate forcing the formation of the bulb and drying down of the top quite early in the season. It becomes necessary, therefore, in these latitudes to devote two years to the maturing of the crop. The first year the ground having been prepared as already directed, though not usually manured quite so liberally, broad, shallow drills, from one to two inches in width, are made about 10 inches apart and these are sown early in spring, very thickly, (the seed nearly covering the ground,) and the crop becomes mature in July, when it is pulled and stored in cool, airy lofts, being spread very thinly over the floor-those raised from the white Portugal onion to a depth of about two inches and those from the yellow sorts to a depth of about four inches. A gentle raking occasionally is of advantage to promote dryness and to prevent sprouting. The yellow variety is the best for keeping, and hence will bear the confinement incident to transportation with less injury, but the clean white appearance of the onion raised from the white setts, give them the preference in the market. Attempts are often made in the north by marketgardeners to raise their own setts and thus save the large outlay often required to purchase them,-- for most of the early onions now used in the northern cities are raised from the setts. The attempts to raise them in the north are mostly a failure, for the reason that the true sett is an onion that has heen checked in its annual growth and dryed down before it has matured it-hence it has an additional growth to make before its annual growth is matured, and before this is matured there can be no seed shoot pushed, for the onion is a biennial plant and the seed shoot belongs to the second year of its growth. When northern gardeners go through the same form of cultivation as those of the south to raise onion setts, the onions grow of small size, but they are for the most part mature onions, notwithstanding, and have attained their yearly maturity, the smallness of size being attained by a crowded cultivation and not by a pre- 
mature formation of the bulb by excessive heat as in the south. The fact that so large a proportion of northern wrown setts push out a seed shoot demonstrates this.

I would suggest that a more scientific mole of procedure would be to plant the seed rather thicker than usual, and then soon after the bulb begins to show itself, thin out the superfluous onions, dropping them between the rows. Such onions though they may appear at times to be about all top, will dry down, if the season favors, and leare nicc little setts for next Spring's use.

Setts are planted in rows about twelve inches apart and two or three inches distant in the row. As the ground worms are very apt to remove them when first planted, the bed should be frequently examincd. Some hold to dropping them in shallow drills, not covering them at all with earth.

Onion setts vary in size from that of a pea to a hazel nut. The smaller the size of the setts the greater the number of onions contained in a given quantity, but many find it for their interest to purchase setts of a good size, as they mature earlier and yield larger onions. The average yield in bulk is about fifty to one. Among the market gardeners in the vicinity of the large cities, onion setts are very extensively planted-some planting as high as 150 bushels annually.

\section{PARERIPES.}

Rareripes are onions raised by planting out bulbs of the growth of the previous season. The rareripe oftentimes differ's from the onion sett only in being a matured onion, as frequently they are about as small as the setts. The method of raising them is the same as with the setts, with the difference of planting them at times at greater distance apart in the row, proportionate with their greater size. The raising of rareripes is a very profitable way of disposing of such onions as are badly sprouted, are very small, or in any way unprofitable for marketing. A seed shoot may be uniformly expected from each onion, but as this greatly deteriorates the quality of the rareripe, making it tough and woody in structure, it should always 
be cut off. If cut off before the swelled growth appears, (a striking characteristic of the onion fumily and a proof of the skill of the Divine Architect, in strengthening by so simple a process the tall, thin stalk designed to support the heavy seed head,) it will again shoot up : wait therefore, until this swelling begins to show itself and then cut below it, and no more trouble from this source will ensue. The smaller the onions planted as rareripes the more handsome will be the crop; the very small ones producing each one handsome round onion, while the large ones produce two or more which are irregular in size.

\section{POTATO ONIONS, TOP ONIONS, AND SHALLOTS.}

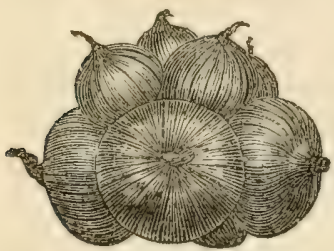

Potato Onions, (see engraving, ) Top Onions, and Shallots are thought by some to have originated from the common onion. It is certain that at times all three of these varieties are sported by the common onion. In a large field of seed onions, occasionally small onions will be found, growing in place of seed, and these onions when set out the ensuing Spring will vegetate and develop readily, but whether they will in turn yield the like, i. e., Top Onions, I need another season to determine.

Potato Ontons, or multiplying onions, are a thick, hard fleshed variety, very mild and pleasant to the taste, and very poor keepers, unless spread very thinly in some dry apartment. They are propagated by planting the bulbs in drills, fourteen inches apart, the larger ones four to six inches apart in the row, and the smaller ones two inches. The small ones rapidly increase and make onions from two to three inches in diameter, while the larger ones divide and make from four to a dozen or even sixteen (usually from five to eight) small, irregularly shaped onions. It will be seen that the larger bulbs answer the same purpose as the seed in the common onion; hence to have onions both for sale and yet maintain the stock, it is necessary that both sizes should be planted.

The Potato onion should be indulged for its best development in a soil rather moister than the varieties from seed. 'The advantage of the Potato onion is its earliness, and the fact that it is not as liable to injury from the onion maggot, when that abounds, as the common sorts. I have seen an instance where on half an acre of each growing side by side, the common onion (that raised from seed) was almost wholly destroyed, while the Potato Onion was nearly uninjured. 
SHallots differ from Potato Onions principally in their characteristic of alvays multiplying; a shallot never grovs into a large round onion; but always multiplies itself, forming bulbs that average more oblong and are usually smaller than those of the Potato onion. I find them xccasionally pushing a seed shoot, which I have never seen in the Potato Onion. Their habit of growth is finer, making a longer and more slender leaf than the Potato Onion. They are mild of flavor and greatly excel every other variety of the onion family in their keeping properties; with little care they may be kept the year round. All seedsmen do not know the difference between the Potato Onion and the Shallot. Within a few years I bave twice had shallots sent me under the name "Potato Onion."

Top Onions are propagated from little bulbs which grow in this variety where the seeds grow in the common sorts. They grow to a large size, are pleasant, mild flavored, rather coarsely and loosely made up, and have the reputation of being poor keepers. Raised like the Potato Onion.

\section{SEED SOWING MACHINES.}

There are a variety of machines in the market for sowing onion and other seed, but most or all of them can be arranged under three classes, viz: Brush Sowers, Snap Sowers, and Drop Sowers.

Brush Machines, are those in which the seed is forced out by a brush contained in the seed box. The characteristic feature in this cliss of seed planters is of English origin and has passed through various modifications in this country. For the gen-. eral purposes of seed sowing, the plan of forcing seed out by a brush is, doubtless, the most reliable.

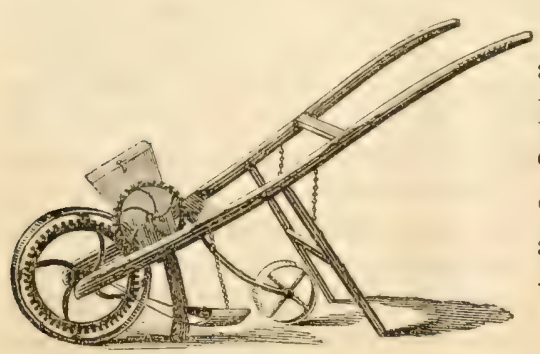

The Brush Machine, an engraving of which is here presented, makes the drills, drops the seed, covers and rolls it; it is adapted for planting all the common root crops.

There is a larger variety of this machire, which, in addition to the smaller seed, sows Corn, Peas, Beans, \&c. For the latter purpose a cylinder is inserted, which revolves perpen.- 
dicularly, and the machine is also so constructed that it may be easily graduated to drop the seed fuster or slower, and make the distances between the hills or drills greater or less as may be desired. The following engraving represents this machine.

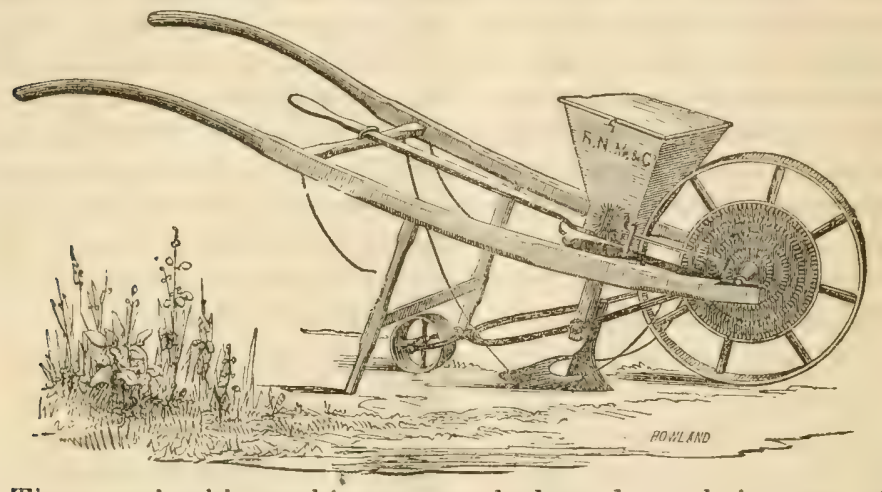

The rows in this machine are marked out by a chain, two of which hang near the handles and drag on the ground, being used alternately. The wheel is pushed along the mark made by the chain.

The principle on which the "Snap." Machine is founded, is the securing the flow of seed through the aperture by a jerking motion, which is usually effected by a spring which makes a snapping noise when set free.

Of the machines built on this principle the one most commonly used in Eastern Massachusetts is known as the Danvers

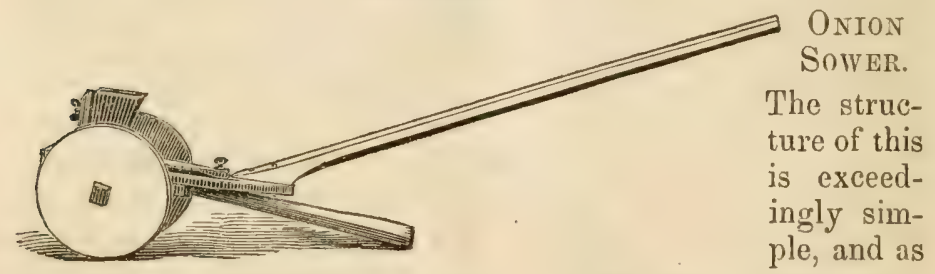

it involves but few parts, and hence is but little liable to get out of order, and when out of order can readily be repaired by any blacksmith, it is quite a favorite with onion raisers. This machine is also used to sow carrot and sage seed.

The Danvers Machine opens the furrows, drops the seed, covers it, but does not roll it. Farmers usually attach an old horse shoe to the end of the seed coverer, which gives sufficient weight to make it answer the purposes of a roller.

In these machines the seed falls through boles in little slides of tin, different slides being substituted as the seed to be 
sown is larger or smaller, or the quantity to be planted is greater or less. Farmers will often find it for their interest to enlarge or diminish the size of these holes. The holes in the tin of the Danvers Sower, to give a liberal sowing of about 4 1-2 lbs. to the acre, should be large enough to drop ten or twelve onion seed to each snap. By putting the hand under and counting the seed which falls in a dozen snappings of the machine a reliable average can easily be ascertained. As the size of onion seed often varies no particular size of bole can be relied upon; it must be tested for each season. Another convenient test is to trundle the machine over the barn floor, or a newspaper spread and secured in the field, and observe how thickly the seed fall. For a beginner the first test is the better one.

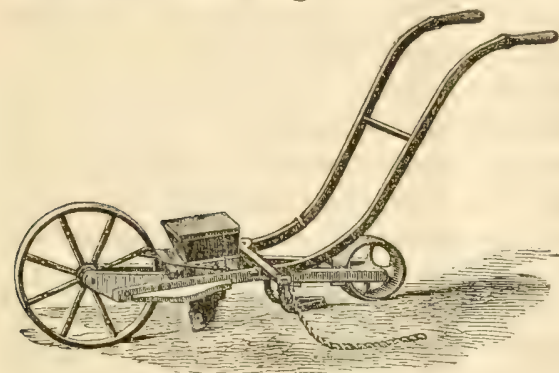

A variety of Snap Machine recently introduced into the market, known as the HARRINGTON MACHINE, (see engraving, ) is giving much satisfaction. Instead of the usual set of tins, it has a disc perforated with holes, of sizes suited for various seed, around

its circumference, and this dise revolves horizontally on its center under the seed box, the aperture suited to the seed to be sown being thus readily presented. It is intended for sowing all ordinary garden produce, including Corn and Beans. It is simple in structure, light and comely in appearance, and is easily moved over the ground. It has given great satisfaction, not only in the sowing of Onion seed, but in the sowing of Beet, Parsnip and Turnip seed; seeds usually very difficult to sow evenly. The peculiar principle of the seed dropper is that of forcing the point of a lancet shaped agitator, edgewise, back and

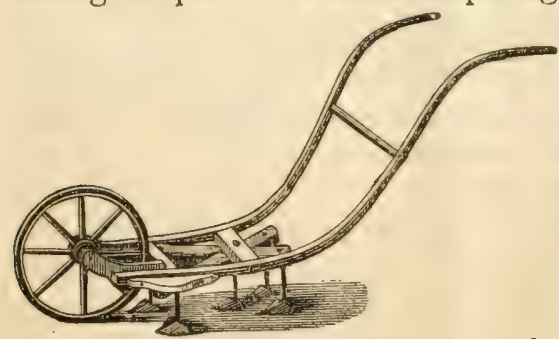
forth through the seed, and directly over the orifice through which the seed are sown, thus keeping the orifice always free. Connected with this Machine is a CuLTIVATOR, (see engraving, which is readily removed when the machine is to be used for planting. In 
most soils the Cultivator works admirably as a hoer and weeder. It has five teeth so arranged as to cut the surface all over, at whatever width the machine is set, cutting up the weeds and pulverizing the soil in the best manner.

Of the Sower which drops the seed in hills, I will treat presently, under the head of "Onions with Carrots."

\section{PLANTING THE SEED.}

Having selected our seed sower and regulated it, the next step is to plant the seed. It is exceedingly necessary that the first row planted should be straight, as this becomes a measure for straightening all the others. A steady hand and a straight eye are of great value here, but with a little practice a good degree of accuracy can be obtained by most persons, though a few will always find it for their profit to hire some experienced hand. Two or three sticks may serve to mark out the first row, and by keeping these bearing on each other as the machine is pushed along, the first line must be a straight line. In some machines the chains which drag from the handle, and in

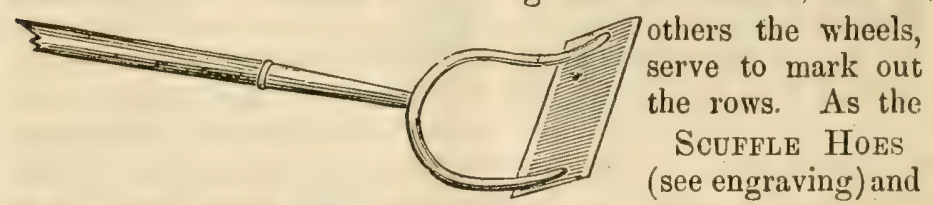

Wheel Hoes (see engraving) to be used will be of a constant

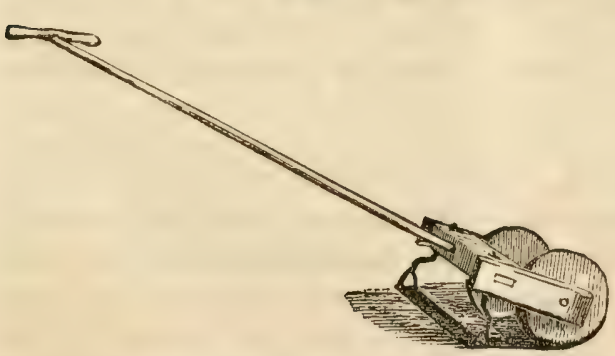

width, it is important that the width of the rows should be kept constant, particularly that they should not be brought nearer together than the distance fixed upon. The distance between the rows varies in different sections from twelve to fourteen inches; when seed are planted for setts ten inches is the usual distance between the drills.

The various hoes used in weeding are pushed before the operator and again drawn quickly back, the operator taking short steps and making the hoe cut in both the forward and backward slides. Farmers sometimes make their own scuffle hoes out of 


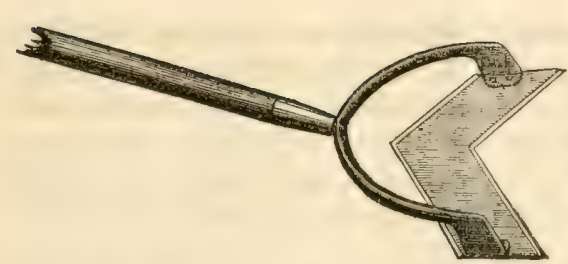

a piece of an old saw, the teeth answering a good purpose in cutting off the weeds. The V shaped hoe, called HowARD's Patent, (see engraving, ) will do excellent service if a weight of about two lbs. be fastened around the handle near the ground.

In Eastern Massacliusetts fourteen inches is the usual distance; while in southern New England and parts of the West, twelve inches is preferred.

Before planting the seed it should be carefully examined, to sce that it is perfectly clean from small stones or any substance that can possibly clog the hole of exit. Let it be remembered when regulating the snap machine, that the seed will not be likely to fall so fast from a full hopper as they will when it is nearly empty. The seed should be sown from half an inch to large inch under the surface. The lighter the soil the deeper the seed may be sown. It is thought that deep sowing has the advantage of getting the plants so deeply rooted that they will bear having the earth slightly pulled away from them in the first weeding, without so much injury as sometimes results when they are planted shallow. While planting, as well as when using the hoe, our farmers will find the advantage of having a finely pulverized surface to work on, free of all clods, sticks and stonesas such will continually vary the straightness of the rows, interfere with the planting and covering of the seed, and, when the hoe is used, glance it out of its course in among the tender plants.

\section{HOEING AND WEEDING.}

In fiom two to three weeks, if the weather is an average for the season, the young plants by a close examination may be seen pushing their green arches above the surface, bearing a close resemblance to a curve of grass. As soon as sufficiently up to enable a sharp eye to determine the course of the rows, without delaying a day or an hour, if the weather permits, the prudent cultivator will slide through his scuffle hoe, as at this season of the year the weather is very uncertain, and the land may hecome too wet to be worked soon after the young plants appear, and yet not too wet to hinder a rapid growth of weeds. On so rich a seed bed, prompt action is very necessary, or a miserably discouraging tangle will soon be the result of negli- 
gence. In their comparative freedom from weeds the cultivators in the West, on their new land, have a great advantage over their brethren in the East. In about a week after the hoe has passed through them, the young plants will need their first weeding with the fingers. This is hand and knee work, and pursued as it has to be in this position at intervals throughout the heat of summer, is to many the most wearying work of the farm.

To protect the knees from sharp stones, "pads" are used, which consist of squares of about eight inches, of several thicknesses of woollen usually covered with leather, which are strapped to the knees. In ordinary seasons onions require three or four hiand-andknee weedings, and from four to six slidings with the hoe. A man's judgment must be his guide. Land newly cultivated to onions will require more frequent weeding than old land that has been well taken care of. As onions shade the ground but slightly, weeds grow rapidly in onions beds, and if they are once allowed to get the start the labor of cultivation is immensely increased. Some cultivators practise scratching the soil away from the onions when weeding, with an old knife curved at right angle near the point, or by a piece of iron hoop curved, the end being nailed to a small piece of wood conveniently held in the hand. Others practise throwing the soil slightly around the young onions with a scuffle hoe made with reference to this use, with a view of smothering the small weeds. When the onions have begun to "bottom down" i. e. form their bulbs, it is the general practice to remove as far as practicable any surplus earth that has accumulated around them. In weeding two or three rows are usually taken together, the weeds being dropped between the rows. Just before the crop ripens down, larger weeds will show themselves here and there over the beds; these are generally gathered in baskets and dropped at the ends of the rows. If the seed of such weeds get ripe before they are pulled, the weeds should be carefully deposited in a pile in some by-place where they can be burned when dry. Growers who practise throwing such weeds to their hogs because they are large and succulent, make an annual seeding of their beds with weeds. Particularly is this true of Pursley, one of the greatest plagues in the heat of the season. The habit of this plant is to ripen the seed, which grows well down on the stalk, while the main bolly of the plant is in its full vigor; hence it usually happen that much seed drops into the land some time before it is pulled, while the farmer never mistrusts it has ripened. I have seen Pursley completely eradicated from garden plots where it formerly was a 
pest, by a little care in this matter of letting it go to seed. The same remarks apply to the weed known as Chick-weed. When blank spots occur from poor seed, poor planting or the ravages of the onion maggot, bush beans, cabbages or tomatoes may be planted.

When the plants are too thick they should be thinnerl; but the beginner had better pull with a sparing hand, for if the ground has been manured very liberally, the crop will do well when the plants are very thickly together, and will oftentimes grow as large when very thick as they will with three times the room. Onion growers like to see their onions piled two or three deep as they grow, the upper layer being entirely out of the ground with the exception of the roots. When the tops beyin to fall over, the onion is rapidly maturing and the bulbs will now grow very fast. Farmers will tell you that "the top is growing down into the bottom." The flat onions begin to bottom late in the season, while the Danvers makes a very encouraging show of bulbquite early. Should the land have been but poorly manured in seasons of drought the crop will be apt to be ripened prematurely, forming a small sized onjon, while those, divided it may be by merely a wall, that have been more liberally manured stand the drought and keep green sufficiently long to receive advantage of the later rains; an investment of twenty dollars in manure thus making a difference sometimes of two hundred dollars in the crop. If the crop is quite backward, late in the season the necks of the onions are sometimes bent over to hasten the formation of the bulb. This is done by hand, or by rolling a barrel over two rows at a time.

\section{S'TORING THE CROP.}

When the necks have fallen over and the great proportion of them are dry, the crop should be pulled by hand and be thrown in winrows, about three rows being thrown into one. At this time all weeds remaining should be pulled and piled preparatory to the final clearing of the bed. The pulling of the crop should not be delayed after the tops are well dry, for if rain should now fall the onions will be apt to re-root to their injury. Should the backwardness of the season make it necessary to pull the crop in rather a green state, it will be well to allow it to remain untouched after pulling for about a week, before turning or stirring, which will tend to hasten the decay of the greener tops; otherwise they should be carefully stirred every pleasant day with a wooden-toothed rake. See that they are not injured by the raking or treading of a careless hand. When the crop is 
thoroughly dried, the onions feeling hard to the handling, it will be ready for topping for market. They are carefully collected in baskets, rejecting all stones, scallions and rotten onions, and taken in wagon loads to the barn and there the tops are cut off clean to the onion with a sharp knife. This is usually done by boys or females at two or three cents by the bushel. While collecting look sharply on the bottom of the onions to detect rotten ones. Some growers prefer to leave such of the crop as they design to keep for a late market untopped. If it is intended to market the crop immediately the onions may be piled to a depth of three or four feet, otherwise they should not be be over two feet in depth. Leave the barn doors and windows all open every pleasant day. As the crop is topped, those of the size of a hazel nut and smaller are classed as pickle onions, these being marketed principally for that purpose, and usually bringing nearly as high a price as the full grown ones.

\section{TRACING, OR ROPING ONIONS.}

When the crop has ripened down but poorly the greener onions are oftentimes traced. This is done by cutting off the neck within about two inches of the bulb and binding it to a handful of straw; beginning at the butt end of the straw, lay the neck against the straw, give two or three firm turns with the twine (net or wrapping twine), add another onion, and thus proceed till the straw is covered, the larger onions being tied to the bottom and gradually decreasing in size to the top. Onions so slowly ripened that they would soon spoil if stored in a mass will keep well when traced, and oftentimes bring a greater profit than the best of the crop. Rareripes, and such of the earlier onions as are to be sent long distances, or be kept awhile before marketing, are usually traced. Traced onions keep in good condition a long while in a dry, cool place.

\section{MARKETING THE CROP.}

The Sett Onions, Potato Onions, Top Onions and Rareripes for the most part, in some sections are sent to market in a green state in bunches. The Potato Onions are brought up from the South dry in large quantities to supply the northern markets, soon after the arrival of the Bermuda Onions, just before the ripening of the Northern crop. After the Potato Onions, follow the earliest variety of the Red, and immediately after, the Danvers, and, finally, the Large Red completes the season. The sales in northern markets early in the season are made mostly for the 
supply of the local immediate demand, the great bulk of the crop not being sent in before the call for shipping purposes has commenced. For this reason, farmers find it to be for their interest to do but little more than feel the market until about the middle of October, as large purchases made previous to this period are mostly as an investment by speculators, with the exception of such lots as go to supply the markets of large towns and cities of the extreme North beyond the limits of the onion growing region.

The price of onions varies greatly; they have sold as low as seventy-five cents a barrel, while the early crop of 1864 sold as high as sixteen dollars per barrel, by the five hundred barrels. From September to March, in the same season, the fluctuation is sometimes between two dollars and six dollars. Crops have at times been sold to be delivered in the course of two months, and in that time have more than doubled in price. The general truth is, that those brought first and those brought latest to market, being kept till near Spring, bring the best prices. The great facilities afforded by onion raising, by the fertile soil and fivoring climate of the West will doubtless, in a few years, tell powerfully on the Eastern Market.

\section{PRESERVING THE CROP.}

If it is the design to keep the crop for a winter market, it should be stored in a conl, dry place, out of danger from frost, in bulk if possible, but not over two feet in depth. It is a good plan to let them rest on a lattice-work of slats on the sides and bottom of the building that the air may circulate through them. If kept in barrels these should not be headed, and should have two or three openings male with a latchet or large auger in the sides near the bottom. If it is designed to keep the onions till Spring, the cheapest and best way is to freeze them. To do this, select the north-west portion of some outbuilding under which the air does not circulate, spread the onions about one and a balf feet in depth, leaving a vacint space of about two feet from the side of the building, let them get thoroughly frozen, then cover them closely with an old sail, or any cloth, to keep the hay from mixing with them, and spread the hay two feet or more in depth above the covering; also pack fine hay closely between the heap and the sides of the building. Here let them remain untouched until the frost is entirely out, when they should be spread at once, well aired, and turned often until thoroughly dried.

If the onions in the fall are not well ripened, or if a larger 
proportion than usual are rotten, which is apt to be the case after a very wet season, or when the onion maggot has given much trouble, to store largely for winter sales is attended with great risk. I have known one enterprising cultivator sink several thousand dollars in a single season by storing heavily under such circumstances.

\section{RUST AND THE MAGGOT.}

The Onion crop is sometimes severely injured by a disease resembling mildew. The tops of the leaves die and the whole plant is more or less covered by patches of this white blast. From the effects of it the onions almost cense their growth and the crop finally obtained is small in size. This disease in some sections is known by the name of "rust." It is more frequent in extraordinary wet seasons, and is more common on old beds than new. The best remedy yet known for old beds is to run the plough a little deeper and thus mix in a little new soil.

The onion magrot is hatched from the eggs of a fly which are deposited in the plant very near the surface of the ground. Its presence may be detected in the crop when very young by the sudden turning yellow and falling over of the plant, when if the attempt is made to pull it, it will usually break off near the surface, and on squeezing several very small maggots will present themselves. Some writers state that the fly deposits its egg's only at an early period in the growth of the plant. It is true that some seasons the injury is most marked previous to the bottoming of the onion, but I have seen beds injured at every stage of their growth, and in one season about half of the crop was destroyed by the inaggot at the close of the season after the onions had been pulled. Various remedies have been proposed but of these it may be said that they are not practical on a large scale. The idea on which most of these is based is that of producing a scent so disagreeable as to drive away the fly; but the old experimenters recall the capacity of the Canker-worm-moth and the Squash beetle to ignore the most repulsive obstructions of this kind when stimulated by their instinct to deposit their eggs. Pine sawdust, either clear, soaked in the urine of cattle, or in the ammoniacal liquor from gas works, scattered over the bed just before the appearance of the plants, at the rate of a bushels to ten square rods; Guano sprinkled along the rows and on the plants twice during the season, unleached ashes used in the same manner; these have given satisfactory results to some growers. Scalding water poured from a common watering pot through a hole the size of a pipestem, along the drills near the roots of the 
plants, and repeated three or four times during a season is said to be efficacious. It is obvious that the practical value of such a remedy nust be confined to a very smali area of land.

In New England the maggot has been slowly making his way from the north, adding greatly to the uncertainty of the crop, until his ravages have extended to Southern Massachusetts. Very light soils appear to be most affected by its ravages. In some seasons the injury done is insignificart, and on the whole the area planted in Massachusetts has not been materially reduced.

It will one year confine ite ravages mostly to one portion of a township and the next season reverse matters; while some tracts are almost never injured, on others it appears to settle down as a permanent resident.

\section{RAISING ONION SEED.}

What does all this investment of money, time, labor and watchfulness amount to if the seed is worthless, has no vitality, is not true to name, or was grown from worthless trash? Onion seed should be raised from the very best onions of the very best crop grown in the vicinity. 'The best type should be first selected, which should be a medium sized onion, very hard and compact in structure, with a close, thin, fine skin, and a very small neck. 'Those selecterl for seed should be the earliest ripened of the crop, provided such are fully ripened and not blighted. To select the earliest onions the seed grower should visit the field before the crop is pulled.

Onion seed is sometimes (I fear too often) grown from the entire crop, be it good, bad or indifferent. A great step of improvement on this is to purchase outright as good a crop as can be found, but the only way to secure and keep the best and most reliable seed is that first given. Poor onion seed is oftentimes very dear indeed, as a present, while first class seed at the highest price yet paid is worth a long and careful seeking.

Seed onions should be kept in a cool, dry place, spread to about a foot in depth; if kept in burrels, these should be left unheaded, and two or three pieces should be chopped off near the bottom to admit a circulation of air. As early in the Spring as the ground can be worked, they should be set out in trenches (the onion when planted in trenches will stand a heavy frost without injury) which should be from three to four feet apart, about four inches below the surface, the land having first been very heavily manured. Some good seed growers apply their manure directly in the trench, while others spread it broadeast and 
plough in. I prefer to plough in a liberal quantity, and then use ashes, Superphosplate of Lime, or Guano in the rows, applying it just before hoeing the crop. If the onions are much sprouted, the sprout may be cut off quite home to the onion, which will insure a straighter and healthier growth. Care should be taken to plant right end up, for odd as it sounds, in the spring it is sometimes difficult to determine which is the right end. As soon as the onior is well rooted, the earth should be drawn up to it, and this should be done three times during the season, until the earth is heaped around them eight or ten inches above the surface of the ground. The first hoeing should be given them very soon after the sprout starts, to fully cover the onion, as when exposed it is very apt to decay. With this support, on land that is not too moist. I find that no further precaution is necessary to keep the seed tops from the ground, though it is the practice of many growers to support with slight strips of wood, or a line drawn along about two feet from the ground. After the last hoeing, (and very clean culture should be given then,) they should be gone among as little as possible.

'T'he seed tops may be safely cut (leaving about six inches of the stem on) when the seed vessels begin to crack; or what is a better guide yet, for after the seed vessels begin to crack much seed is apt to be lost, especially by heavy storms, is the turning yellow, near the ground, of the seed stalk; when this occurs the top may be removed immediately, even though it should appear quite green above.

Seed tops will be often found in which the seed in the shortest stemmed receptacles is ripened, and the receptacles themselves are cracked, while a fresh growth of seed vessels in a green state almost conceals them; in such cases I would advise the cutting of the top. The tops thus cut should be spread to a depth of six inches or less, in a warm place where heat and air abound, and be turned two or three times daily: until thoroughly dried, when the seed is ready to be threshed out; or it may be stored in barrels in a dry loft, and threshed as wanted. If the seed is plump and has been well ripened, the frequent turning of the stalks will have shaken out by far the larger proportion of it-in some seasons more than five-sixths of it.

As the seed stalks make but little shade, the ground between the rows can be profitably cultivated to Spinach, Lettuce, Radishes, Turnips, or such early vegetables, and when these are harvested be planted to cucumbers for pickles. The planting between the rows should be confined to the middle, and in trenches an inch or so below the surface, unless it be made after 
the onions have received their final hoeing, otherwise the drawing of the earth around the seed stalks will seriously interfere with these crops.

Strange as it may sound to those who have not tried it, such rampant growers as squashes can be raised among seed onions with no material injury to the seed. I bave known five tons of Hubbard Squashes grown on about half an acre of ground planted to seed onions. The squash should be planted - towards the close of May, after the onions have received their final hilling, two or three seed being planted close to every other row, and about nine feet apart in the row; allow but one plant to grow in a hill. The vines thus having plenty of room between the rows to spread about do not incline much to climbing on the seed stalks. Care should be exercised to break off at once the tendrils of such as attempt to climb. The one plant to the hill system will be found to yield as liberal a crop and finer squashes than the old system of three or four to the hill.

The yield of onion seed to the barrel of seed onions varies greatly; indeed, no investments near the seaboard prove more speculative. The maggot sometimes proves very destructive so much so, that the crop will not average half a pound to the barrel, when under very favoring circumstances crops have been raised which averaged eighteen pounds to the barrel.

When the seed is fully dry, (and seed that has been sunk should have a long exposure to the air and frequent stirrings; I have known large lots spoilt from want of care in this,) it should be so stored as to be safe from all injury from cats and other animals, who are apt to resort to it, to the utter destruction of its vitality.

\section{RAISING CARROTS WITH ONIONS.}

The plan of raising carrots with onions is considered a great improvement by many who have adopted it, as the yield of carrots is thought to be a clear gain, diminishing but little or none the yield of onions. Carrots are planted in two ways ; one by sowing them in drills between every other row of onions, and the other, which is considered an improvement, called the Long Island plan, by planting the onions in hills from seven to eight inches from center to center dropping a number of seed in each hill, and from the first to the twelfth of June planting the carrot seed, usually by hand, between these hills in two rows, then skipping one, and thus on through the piece. The onions, as they are pulled are thrown into every third row, the carrots being left to mature. By this method from two hundred to six hun- 
dred bushels of carrots are raised in addition to the usual crop of onions. More manure is required for the two crops than for onions alone.

The Machine used for sowing in drills has two boxes attached to the axle at equi-distance from the wheels; there are three or four holes in the axle that communicate with the seed in the boxes, and as these holes pass under the boxes they are filled with seed, and as they turn the seed are dropped into the earth. Screws are sunk into the holes which can be sunk more or less at pleasure, and the quantity of seed which the holes will contain is thus graded.

The machine should first be tested and so regulated that on a barn floor it will drop from eleven to twelve seed from each hole. When so regulated, on using in the field it will drop but from seven to twelve, owing to the more uneven motion.

This, like all sowing machines, and the same may be said of the scuffle hoe and wheel hoe, is pushed along before the operator.

My farmer friends, I have now given you the result of my own experience in the raising of Onions, Potato Onions, Top Onions, Shallots, and Unions Setts, combined with the experience in onion growing of a neighborhood where a hundred thousand bushels are raised annually, with the results of personal observation in other localities, and with facts that I have collected by corresponding with different sections of the United States.

I hope this contribution will prove acceptable.

\section{JAMES J. H. GREGORY.}

Marblehead, Mass. 


\section{An Agricultural Library for Five Dollars.}

\section{GOOOD BOOKS AT OLD PRICES.}

THE PAPER AND BINDING WORTH THE MONEY.

\section{SIX VOLUMES OF THE \\ GENESEE F A R M R}

Nearly Two Thousand Pages, Over Five Hundred Engravings.

Those acquainted with THE GENESEE FARMER will be glad to avail themselves of this opportunity to secure a set of the Bound Volumes at rates far less than they can now be published: No Farmer, Fruit Grower, or Horticulturalist should be without a set of these Bound Volumes. They are invaluable for reference. There is scarcely a subject in the whole range of Agricultural and Horticultural practice that is not treated on. They will be worth ten times their cost to any farmer.

THE GENESEE FARMER is published in one of the best wheat and fruit sections in the United States. It is a Monthly Journal of 32 Royal Octavo Pages, filled with carefully prepared matter of great practical value to all engaged in the cultivation of the soil. The twelve monthly numbers are bound together in a substantial manner, making a handsome book that is worth a place in any library. There is a complete Index to each volume.

The volumes for the last six years, (1859-1860-1861-1862-1863-1861) will be sent by express for five dollars.

The volume for 1864 will be sent separately by mail, prepaid, for $\$ 1.25$.

The Genesee Farmer for 1865 , will be sent to any address for $\$ 1.00$.

Rural Annual 1865, 25 cts. prepaid by mail.

\section{THE RURAL ANNUAL AND HORTICULTURAL DIRECTORY}

Is a little work of 120 pages, published at the commencement of each year by the editor of the GENESEE FARMER. It was started in 1856 , and a new volume, containing entirely new matter has been published each year. The complete set of eight numbers, (1856, '57, '58, '59, '60 61 , '62 and 63,) handsomely bound in two volumes, will be sent to any address, prepaid, by mail, on receipt of $\$ 2.50$.

The six volumes of the GeNESEE Farmer, for the years '59, '60, '61, '62, '63 and '64, ) and the complete set of the RuRal ANvoal, handsomely bound, will be sent together by express foe \$7.00. Address,

\section{JOSEPH HARRIS,}

Publisher and Proprietor Genesee Farmer \& Rural Annual. ROCHESTER, N. Y. 
A Good, Cheap, and very Valuable Paper for Every Man, Woman, and Child, In City, Village, and Country. THE

\section{AMERIOAN AGRICULTURIST}

EOR THE

\section{Farm, Garden, and Household,}

Including a Special Department of Interesting and Instructive 1Reading for CHULDRFiN and XOU'TH.

The Agriculturist is a large periodical of thirty-two quarto pages, beautifully printed, filled with plain, practical, reliable, original matter, and enntaining hundreds of beautiful and instructive Engravings in every annual volume.

It contains, each month, a Calendar of Operations to be performed on the Farm, in the Orchard and Garden, in and around the Dwelling, etc.

The thousands of hints and suggestions given in every volume are prepared by practical, intelligent working men, who know what they write about.

The Household Department is valuable to every Housekeeper, affording very many useful hints and directions, calculated to lighten and facilitate in-door work.

The Department for Children and Youth is prepared with special care, to furmsh not only amusement, but also to inculcate knowledge and sound moral principles.

TERMS-English Edition. The circulation of the American AgriculIurist (more than one hundred thousand) is so large that it can be furnished at the low price of $\$ 1.50$ a year; four copies, one year, for $\$ 5$; ten copies, one year, for $\$ 12$; twenty or more copies, one year, $\$ 1$ each; single copies 15 cents each.

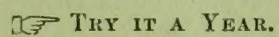

A GERIMAN EDITION, containing all the principal articles and engravings of the English edition, and other matter of special interest to German Americans, is furnished at $\$ 2$ a year; four copies, $\$ 7$; six copies, $\$ 10$; ten or more copies, $\$ 1.50$ each.

ORANGE JUDD, Publisher and Proprietor. No. 41 PARK ROW, NEW-YORK CITY. 